\title{
Interactions between endophytic bacteria and their effects on poaceae growth performance in different inoculation and fertilization conditions
}

\author{
Elisiane Inês Dall'Óglio Chaves*1,2 ${ }^{1,}$ Vandeir Francisco Guimarães ${ }^{1}$, Eliane Cristina Gruszka Vendruscolo ${ }^{2}$, \\ Marise Fonseca dos Santos ${ }^{2}$, Fernanda Freitas de Oliveira ${ }^{2}$, Joel Antônio Cordeiro de Abreu ${ }^{2}$, Maiara Pasuch \\ Camargo $^{2}$, Vanessa Suzane Schneider ${ }^{2}$, Emanuel Maltempi de Souza ${ }^{3}$, Leonardo Magalhães Cruz ${ }^{3}$, Edmar \\ Soares de Vasconcelos ${ }^{1}$
}

\author{
${ }^{1}$ West State University of Paraná (UNIOESTE) - Campus Marechal Cândido Rondon - PR, Brazil \\ ${ }^{2}$ Federal University of Paraná (UFPR) - Campus Palotina - PR; ${ }^{3}$ Federal University of Paraná (UFPR) - Campus \\ Curitiba - PR, Brazil
}

\begin{abstract}
Plant growth-promoting bacteria (PGPB) are a broad group of microorganisms that offer a huge, unexplored potential. We assessed the genetic diversity of endophytic bacteria that were isolated from corn and wheat plants in 3 different types of soils: A1 (Red Argisol), A2 (Red Latosol) and A3 (Red Nitossol). Endophytic bacteria were isolated from seedlings using 7 solid culture media and were further analyzed by $16 \mathrm{~S}$ gene sequencing. IAA (Indole-3-acetic acid) production and PSI (Phosphorus solubilization index) bacteria capacity were tested in a randomly scheme in triplicate. In vitro association was assayed with 6 randomly selected endophytic strains. The experiment design was arranged in a randomly scheme with 10 replications. In vivo assays were performed to evaluate plant growth promotion using a low-fertility soil in different inoculation and/or fertilization conditions. The experiment design was arranged in a factorial $3 \times 4$ scheme in triplicate. The following characteristics were evaluated in both experiments in triplicate: plant biomass, total nitrogen content (TN) and endophytic population. As results, a total of 136 isolates were collected, and from these isolates, 41 strains were sequenced and classified into 4 major phylogenetic categories. There was a 38-fold variation between the highest (Ensifer adhaerens) and the lowest (Agrobacterium larrymoorei) IAA producer, and only $14 \%$ of strains were high phosphate solubilizers. In vitro assays identified both positively (Burkholderia ambifaria) and negatively (Pantoea ananatis) associative strains. In vivo assays showed that plant genotype can limit or induce the endophytic microbiota and that plant microbiota are highly influenced by soil fertility.
\end{abstract}

Keywords: 16S rDNA sequencing, plant bacteria interaction, plant growth promotion, inoculant.

Abbreviations: BNF_biological nitrogen fixation; IAA_Indole-3-acetic acid; PGPB_Plant growth-promoting bacteria; PSI_Phosphorus solubilization index.

Introduction

Cereals such as corn and wheat are economically important due to their use in human diets. Both crops have several limiting factors in their development, including the requirement of fertilizers for essential metabolic functions that directly influence grain productivity (Hawkesford, 2014). Productivity increases are correlated with the use of appropriate management practices, including an appropriate nutritional supply.

In this context, the use of chemical fertilizers is essential for crop production. However, the cost of these fertilizers, their limited availability and the associated environmental issues create an urgent need to find alternative strategies that reduce their environmental impact and their production costs without incurring farmer losses (Reis 2007; Rojas-Tapias et al.,, 2012; Majeed et al.,, 2015). Plant-growth-promoting bacteria (PGPB) are free-living bacteria in the soil that aggressively colonize the rhizosphere of plants and directly enhance root and plant growth through biological nitrogen fixation (BNF) and phosphate solubilization. They indirectly impact root and plant growth through phytohormone stimulation (indole acetic acid, cytokinin, gibberellins) and by providing protection against pathogens and abiotic stress (Farrar et al., 2014; Prathap and Kumari 2015; Rolli et al., 2015).

Microorganisms represent the greatest wealth of biochemical and molecular diversity in nature. Countless studies have been conducted to study the isolation, characterization and identification of PGPB in grasses (Khalid et al., 2004; Roesch et al., 2007; Ilyas and Bano 2010; Arzanesh et al., 2011; Rashid et al., 2012; Arruda et al., 2013). Other studies have investigated plant-bacteria interactions (Weyens et al., 2009; Beneduzi et al., 2013; Hardoim et al., 2015) and have demonstrated their potential agricultural and environmental applications, such as the control of diseases and pests (Compant et al., 2005; Mendes et al., 2007), the promotion of plant growth (García 
de Salamone et al., 2012; Rojas-Tapias et al., 2012), the biological fixation of nitrogen in plants, the production of metabolites of pharmacological and biotechnology interest (de-Bashan et al., 2004), the creation of vectors to introduce genes of interest into plants (Murray et al., 1992) and the production of organic products that reduce the need for fertilizers in nature (Sala et al., 2008; Singh et al., 2011), among others.

Farmers constantly demand technologies that reduce costs and achieve eco-sustainable alternatives. Thus, studies involving the isolation, characterization and identification of diazotrophs that associate with cereals are necessary and promising. Currently, molecular techniques can be used for taxonomic classification, enabling the assessment of phylogenetic relationships among strains and the evaluation of bacterial community composition (Lagos et al., 2015). The $16 \mathrm{~S}$ ribosomal gene has been used to build an outline of the bacterial evolutionary tree. Several molecular analyses have been conducted from PCR products. The technique used to analyze fragment gene sequences enables direct evaluation of DNA polymorphisms, which can be used to determine relatedness between individuals and populations. These data provide phylogenetic inferences and enable assessment of the endophytic communities (Ahmad et al., 2009; Gaiero et al., 2013).

To recommend an inoculant for commercial purposes, trials that transition from laboratory (in vitro) to field conditions are necessary to select bacterial strains with consistent plantgrowth-promoting abilities. Therefore, this paper aims to isolate and characterize bacterial strains that present significant enhancements in plant growth promotion in cereals.

Results

\section{Phenotypic characterization of bacterial isolates}

Bacterial strains were isolated based on morphology and were distributed as follows: for wheat roots, 17 isolates were collected from A1 (Red Ultisol), 21 from A2 (Red Latosol) and 17 from A3 (Red Nitossol); for corn roots, 26 different bacterial strains were isolated from A1, 28 from $A 2$ and 27 from $A 3$ (Table 1). The soil with the highest number of isolates was $A 2$ (36\%). The soil types were not significantly different in terms of bacterial adherence, as the average number of isolates was 45 in all soil types. Based on the culture medium, $11 \%$ of the isolates were obtained in DYGS, $11 \%$ in NFB, $18 \%$ in JNFb, $12 \%$ in LG, $19 \%$ in LGD, $14 \%$ in LGI and $15 \%$ in LGI-P. All bacterial isolates grew between $28-30^{\circ} \mathrm{C}$ except for those in LGI medium $\left(35-37^{\circ} \mathrm{C}\right)$. Among the isolates, 49 were classified as bacilli, one as streptococcus, 2 as diplococci and 84 as other cocci. Colonies were colorless (66 isolates), white (41), cream (1) and yellow (28). Most of the isolated colonies were gram negative (91\%), while only 12 strains (9\%) were gram positive.

Out of the 136 isolates, 41 had 165 rDNA sequences. The genera identified through $16 \mathrm{~S}$ rDNA analysis grouped in 4 bacterial divisions (Fig.1). The gammaproteobacteria division was composed of Pantoea (12), Pseudomonas (1), and Acinetobacter (1). The alphaproteobacteria division included Agrobacterium (15) and Ensifer (1). Burkholderia (5) was the prominent genus found in Betaproteobacteria. The Firmicutes division included Bacillus (3) and Brevibacillus (1).

\section{Bacterial phosphate solubilization and IAA production}

Sequenced isolates differed in their capacity for phosphate solubilization and IAA production. For phosphate solubilization, regardless of the area and culture, 25 isolates (63\%) showed no phosphate solubilizing capacity. Furthermore, $14 \%$ had a low solubility index ( $\mathrm{SI}<2), 9.3 \%$ had a medium index (IS $<4$ ), and $14 \%$ had a high index (IS $\geq 4)$, with a high potential for biofertilization (Table 1). Red Ultisol soil (A1) showed the highest number of good solubilizing strains, which is likely due to its low $\mathrm{pH}(\mathrm{pH}$ 4.8). The isolates with a high capacity for phosphate solubilization belong to the genera Burkholderia, Bacillus and Agrobacterium. Bacterial controls used in this experiment were $H$. seropedicae and $A$. brasilense, which have no phosphate solubilizing capacity.

Bacterial isolates had IAA values ranging from $30.31 \mu \mathrm{g} \mathrm{mg}$ protein $^{-1}$ (Agrobacterium larrymoorei) to $1170.98 \mu \mathrm{g} \mathrm{mg}$ protein $^{-1}$ (Ensifer adhaerens), a 38-fold variation. Many of the isolates were better IAA producers than $A$. brasilense and $H$. seropedicae, which demonstrates the great diversity of IAA production across bacteria.

\section{In vitro plant growth promoting assay}

The results of the in vitro associative ability of isolates with wheat plants are shown in Table 2. When associated with wheat, strain M 3-87 (Burkholderia ambifaria) promoted a significant increase in root length. The high fresh weight of the shoot was likely due to its high IAA production capacity, which corresponds to an increased root length and improved interaction with plants. This isolate contained the largest number of endophytic cells (CFU) $\left(1.3610^{6} \mathrm{CFU} \mathrm{mL}^{-1}\right)$.

While strain T 1-14 (Pantoea ananatis) presented an epiphytic and endophytic population, it had limited ability to increase root biomass and seemed to have a deleterious effect in inoculated seedlings. Strain M 2-77 (Enterobacter asburiae) failed to interact with host plants, and T1-1 (Agrobacterium tumefaciens) presented an intermediate performance in terms of plant growth. A. brasilense (control strain) presented relatively high epiphytic colonization, and $H$. seropedicae showed a relatively high endophytic colonization in wheat seedlings, increasing TN, but there was no effect on plant growth.

\section{In vivo plant growth promoting assay}

Wheat and corn belong to the same botanical family, but they respond differently to the presence of inoculation and/or fertilization in pots (Table 3). Strains M3-87 and T1-14 were chosen by their prior positive and negative responses. In both plant species, the presence of these strains showed a positive effect on TN content. In wheat, the results were collected from three groups (I, II and III) in which various bacterial genera and/or fertilization conditions were applied. A. brasilense increased TN by $69 \%$, while this strain plus NPK and ammonium sulfate produced a $154 \%$ increase in TN compared to the control. The same effect was observed in T 1-14, where the TN increased by $58 \%$ and $154 \%$, respectively, in the above- 
described conditions. Strain M 3-87 did not respond with an increase in TN content, although M 3-87 was isolated from corn plantlets and showed a better affinity with wheat in vitro than did T 1-14.

In corn, the best response in height, fresh and dry weight was found when NPK and/or ammonium sulfate was applied to the plants (Table 3). A. brasilense T 1-14 and M 3-87 increased TN by $43 \%, 46 \%$ and $52 \%$, respectively, compared to the control plants. The results indicate a decreasing epiphytic and endophytic microbial population due to chemical fertilizers. However, T 1-14 was an exception, as ammonium sulfate produced a higher CFU (5.7 $\mathrm{x}$ epiphytic and $8.7 \mathrm{x}$ endophytic) compared to the control. Numerically, this reduction was greater when NPK and ammonium sulfate were applied, which demonstrates the bacterium's sensitivity to fertilizers. Reinoculated T 1-14 (Pantoea ananatis) did not demonstrate significant differences in vitro, but it had a positive effect in pots.

\section{Discussion}

Isolating and characterizing a prodigious strain for use as biofertilizer is a difficult task; the strain must have the capacity to associate with different plants by overcoming the plant's immune system to establish an association. Additionally, the ideal strain should be an IAA producer and a macro- and micronutrient solubilizer, among other features. To colonize plants, bacteria should be able to recognize, adhere, invade and grow as a population. These characteristics could reduce the diversity of PGPB for biotechnological purposes due to plant and bacterial genotype dependence (Berg 2009).

Gammaproteobacteria and alphaproteobacteria were the major poaceae endophytic bacterial groups observed. Betaproteobacteria and firmicutes were also found. Donn et al., (2015) in a cross-year analysis of the soil microbiome in an intensive wheat cropping system, revealed a microbiota dominated by Proteobacteria, Actinobacteria and Bacteroidetes. Romero et al., (2014) and Chaturvedi and Singh (2016) reported that the most common genera of endophytes are Pseudomonas, Burkholderia, Stenotrophomonas, Micrococcus, Pantoea, Microbacterium, and Bacillus. The results noted a prevalence of Rhizobia strains, which was also observed by Romero et al., (2014). Majeed et al., (2015) observed that Stenotrophomonas spp. seem to prefer wheat plants as a host, which is similar to what we observed in this study (Table 1). Moreira et al., (2016) observed that the most abundant genera in cultivated wheat were Pseudomonas, Burkholderia and Enterobacter in 346 isolates.

There was not a clear association between endophytic genera and the soil or plant type used as bait (Table 1 ). The 41 sequenced isolates may not represent all of the diversity in the evaluated soils. In the literature, several authors reported that soil type is the major determinant in the structure of microbial communities. Additionally, the organic matter content, texture and structure, microaggregate stability, $\mathrm{pH}$ and the presence of essential nutrients such as $\mathrm{N}, \mathrm{P}$ and Fe can determine microbial niches. Furthermore, other factors such as soil management, crop rotation, and the use of herbicides, fertilizers and irrigation must be considered (Dey et al., 2012;
Arruda et al., 2013; Moreira et al., 2016). Although the sampled soils correspond to three distinct types (Red Ultisol, Red Latosol and Nitossol), they do not differ greatly in their physical and chemical characteristics. All soils had a high sand content and a pH of approximately 5.0 (Table 4), which would explain the presence of similar microbiota. Red Argisol type (A1), which was sandier and had a lower OM content than the others, presented the highest species diversity, with 21 distinct isolates (Table 2).

Strain T 2-32 (Ensifer adhaerens) would be an interesting strain to test in further experiments because of its stunting IAA production (1170.98 $\mu \mathrm{g} \mathrm{mg}$ protein ${ }^{-1}$ ) compared to $A$. brasilense AbV5 (commercial inoculant) or $H$. seropedicae (positive control) (Table 1). Among the isolates, Agrobacterium, Bacillus and Burkholderia were considered the strongest $\mathrm{P}$ solubilizers; this result has been confirmed by others (Rodríguez \& Fraga 1999; Castanheira et al., 2016; Moreira et al., 2016).

In vitro strain selection may contribute to a better screening of potential biofertilizer strains, especially in gnotobiotic conditions, where environmental aspects could mask plant and bacterial interactions (Khalid et al., 2004; Fürnkranz et al., 2009). The results demonstrate the outstanding performance of $\mathrm{M}$ 3-87 in promoting root and aerial growth, qualifying this species as a PGPB (Compant et al., 2008). T 1-14 (Pantoea ananatis) had a negative effect on plantlet growth (Table 2 ). This observation is compatible with the fact that the plant might perceive this species as a pathogen; it could also be the result of phytotoxin production inhibiting plant growth (Compant et al., 2008).

In vivo experiments are useful to check interactions between inoculate and natural soil microbiota. The microbial population linked to the corn plant was larger than that linked to wheat in the control plants, which is likely due to more abundant and diverse exudates in corn than in wheat. Several authors reported the effect of plant genotype on bacterial communities due to the stimulation of secondary compounds (Doornbos et al., 2012; Bouffaud et al., 2012; Hardoim et al., 2016; Kirzinger \& Stavrinides 2016). Dey et al., (2012) reported that plants exude a wide variety of compounds, such as ethylene, sugars, and amino acids. These compounds are determined by plant genotype and directly influence the rhizospheric community. These compounds or signals can generate a specificity in plant and bacteria due to genotype and strain dependence (Drogue et al., 2012). Other authors also report that the amount and composition of exudates varies along the root length, with soil fertility and in biotic and abiotic stresses (Neumann 2007; Marschner et al., 2011). In corn, exudates are composed of $65 \%$ sugar, $33 \%$ organic acids and 2\% amino acids (Baudoin et al., 2003; Aira et al., 2010). However, few studies have addressed the characterization of exudates in various wheat cultivars. It is important to note that soil microbiota could have an important role in increasing soil fertility, but our results showed that low fertility almost failed to promote the natural bacterial population that was observed in the control wheat plants. On the other hand, Egamberdiyeva (2007) reported that a positive bacterial associative capacity in wheat was correlated with the nutritional status of the soil, where the best results were obtained in low fertility soils. 
Table 1. Number of phosphate solubilizers and IAA producers by bacterial isolates in each sampling site.

\begin{tabular}{|c|c|c|c|c|}
\hline Sample Number & Isolate & Related bacteria & PSI & IAA Content $\left(\mu \mathrm{g} \cdot \mathrm{mg}^{-1}\right)$ \\
\hline 1 & T 1-1* & Agrobacterium tumefaciens & - & $60.22 \mathrm{e}$ \\
\hline 2 & T 1-2 & Agrobacterium tumefaciens & - & $97.00 \mathrm{e}$ \\
\hline 3 & T 1-3 & Agrobacterium tumefaciens & - & $99.6 \mathrm{e}$ \\
\hline 4 & T 1-4 & Agrobacterium tumefaciens & - & $187.68 \mathrm{~d}$ \\
\hline 5 & T 1-5 & Shigella flexneri & - & $192.06 d$ \\
\hline 6 & T 1-6 & Agrobacterium tumefaciens & - & 59.97e \\
\hline 7 & T 1-8 & Shigella flexneri & - & $82.43 \mathrm{e}$ \\
\hline 8 & T 1-10 & Burkholderia unamae & - & $106.10 \mathrm{e}$ \\
\hline 9 & T 1-11 & Agrobacterium tumefaciens & - & $193.90 d$ \\
\hline 10 & T 1-13 & Stenotrophomonas rhizophila & - & $72.56 \mathrm{e}$ \\
\hline 11 & T 1-14 & Pantoea ananatis & $3.13 d$ & $81.65 \mathrm{e}$ \\
\hline 12 & T 1-16 & Agrobacterium tumefaciens & - & $161.43 d$ \\
\hline 13 & T 2-21** & Pseudomonas chlororaphis & - & $292.42 c$ \\
\hline 14 & T 2-23 & Shigella sonnei & - & $446.54 b$ \\
\hline 15 & T 2-26 & Escherichia fergusonii & - & $268.97 c$ \\
\hline 16 & T 2-28 & Shigella flexneri & $2.91 d$ & $73.81 \mathrm{e}$ \\
\hline 17 & T 2-32 & Ensifer adhaerens & - & $1170.98 a$ \\
\hline 18 & T 2-36 & Escherichia fergusonii & - & $234.54 c$ \\
\hline 19 & T 2-37 & Acinetobacter johnsonii & - & $100.13 \mathrm{e}$ \\
\hline 20 & T 3-45 & Escherichia fergusonii & - & $382.67 \mathrm{~b}$ \\
\hline 21 & T 3-46 & Pantoea vagans & - & $84.83 \mathrm{e}$ \\
\hline 22 & T 3-51 & Agrobacterium tumefaciens & - & $80.22 \mathrm{e}$ \\
\hline 23 & M 3-56*** & Agrobacterium radiobacter & $1.31 \mathrm{e}$ & $115.89 \mathrm{e}$ \\
\hline 24 & M 3-72 & Agrobacterium radiobacter & $1.38 \mathrm{e}$ & $234.21 \mathrm{c}$ \\
\hline 25 & M 2-77 & Enterobacter asburiae & - & $180.38 d$ \\
\hline 26 & M 3-80 & Acinetobacter johnsonii & - & $46.67 \mathrm{e}$ \\
\hline 27 & M 3-87 & Burkholderia ambifaria & $4.48 \mathrm{c}$ & $340.93 b$ \\
\hline 28 & M 2-91 & Enterobacter asburiae & $3.05 d$ & $69.13 e$ \\
\hline 29 & M 2-93 & Bacillus safensis & $3.32 d$ & $97.05 \mathrm{e}$ \\
\hline 30 & M 2-95 & Agrobacterium fabrum & $6.60 a$ & $223.68 c$ \\
\hline 31 & M 3-101 & Burkholderia unamae & - & $166.70 d$ \\
\hline 32 & M 3-103 & Bacillus thuringiensis & $6.98 a$ & $88.24 \mathrm{e}$ \\
\hline 33 & M 1-118 & Burkholderia cepacia & $5.01 b$ & $71.61 \mathrm{e}$ \\
\hline 34 & M 1-119 & Agrobacterium fabrum & $1.17 \mathrm{e}$ & $134.77 d$ \\
\hline 35 & M 1-120 & Agrobacterium fabrum & $1.16 \mathrm{e}$ & $238.79 c$ \\
\hline 36 & M 1-121 & Agrobacterium fabrum & $6.78 a$ & $62.49 \mathrm{e}$ \\
\hline 37 & M 1-122 & Burkholderia sp. & $5.34 b$ & $158.19 d$ \\
\hline 38 & M 1-127 & Escherichia fergusonii & $1.31 \mathrm{e}$ & $82.11 \mathrm{e}$ \\
\hline 39 & M 1-128 & Bacillus megaterium & $1.19 \mathrm{ef}$ & $164.94 d$ \\
\hline 40 & M 1-133 & Brevibacillus agri & - & $126.08 d$ \\
\hline 41 & M 1-135 & Agrobacterium larrymoorei & - & $30.31 \mathrm{e}$ \\
\hline Control 1 & SMR1 & Herbaspirillum seropedicae & - & $135.76 \mathrm{~d}$ \\
\hline Control 2 & AbV5 & Azospirillum brasiliense & - & $90.08 \mathrm{e}$ \\
\hline
\end{tabular}

*T 1-1:T means isolated from wheat, 1-isolated in A1 (Red Ultisol - Iporã/PR), 1- the $1^{\text {st }}$ isolated

**T 2-21: T means isolated from wheat, 2-isolated in A2 (Red Latosol - Line La Salle-Palotina/PR) 21- the $21^{\text {th }}$ isolated

***M 3-56: $\mathrm{M}$ isolated from corn, 3-isolated in A3 (Red Nitosol - Line Aparecidinha-Palotina/PR)., 56- the $56^{\text {th }}$ isolated

PSI- phosphate solubilizing index

IAA-Indole acetic acid 


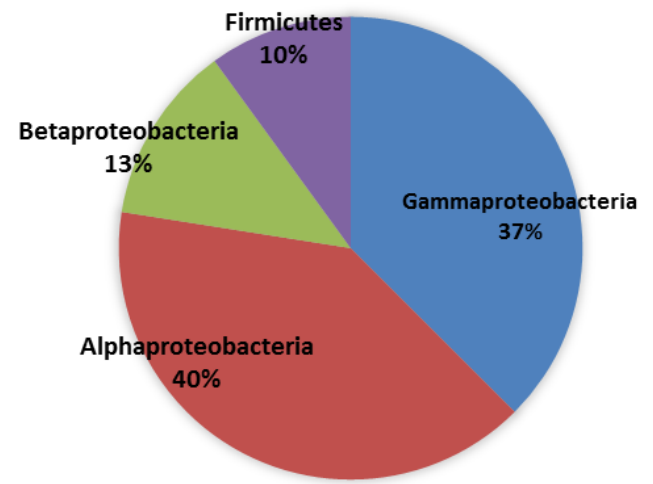

Fig 1. Taxonomic classification from isolated bacteria in 3 different types of soil through analysis of $16 \mathrm{~S}$ rRNA sequences.

Table 2. In vitro morphophysiologic and biochemistry characterization of different strains inoculated in wheat plantlets.

\begin{tabular}{|c|c|c|c|c|c|c|c|c|c|c|c|}
\hline & \multicolumn{11}{|c|}{ Biochemistry characterization of bacterial strains } \\
\hline & Isolates & $\begin{array}{l}\text { Root } \\
\text { Length } \\
(\mathrm{cm})\end{array}$ & $\begin{array}{c}\text { Fresh } \\
\text { Aerial } \\
\text { Biomass } \\
\text { (mg) }\end{array}$ & $\begin{array}{c}\text { Dry } \\
\text { Aerial } \\
\text { Biomass } \\
\text { (mg) }\end{array}$ & $\begin{array}{c}\text { Fresh } \\
\text { Root } \\
\text { Biomass } \\
\text { (mg) }\end{array}$ & $\begin{array}{c}\text { Dry Root } \\
\text { Biomass } \\
\text { (mg) }\end{array}$ & $\begin{array}{l}\text { Total N } \\
\left(\mathrm{g} \mathrm{Kg}^{-1}\right)\end{array}$ & $\begin{array}{l}\text { Epiphytic cells } \\
\left(\text { CFU } \times 10^{6} \mathrm{~mL}^{-1} \text { ) }\right.\end{array}$ & $\begin{array}{l}\text { Endophytic cells } \\
\left(\text { CFU } \times 10^{6} \mathrm{~mL}^{-1} \text { ) }\right.\end{array}$ & PSI & $\begin{array}{c}\text { IAA/Protein } \\
\left(\mu \mathrm{g} \mathrm{mg}^{-1}\right)\end{array}$ \\
\hline T 1-1 & Agrobacterium tumefaciens & $12.50 \mathrm{~b}$ & $43.18 \mathrm{c}$ & $6.01 b$ & $70.00 a b$ & $8.33 a$ & $59.50 a$ & - & 0.20 & - & $60.22 \mathrm{~b}$ \\
\hline T 1-14 & Pantoea ananatis & $10.00 \mathrm{bc}$ & $22.96 d$ & $2.68 c$ & $27.00 \mathrm{c}$ & $6.33 a b$ & $43.80 f$ & 1.90 & 0.13 & $3.13 b$ & $81.65 b$ \\
\hline M 3-87 & Burkholderia amfibaria & $15.50 a$ & $67.01 \mathrm{a}$ & $21.50 a$ & $63.00 a b$ & $8.00 a b$ & $45.30 \mathrm{e}$ & 0.31 & 1.36 & $4.49 a b$ & $340.93 a$ \\
\hline$A b-V 5$ & Azospirillum brasilense & $6.50 \mathrm{de}$ & $53.28 b$ & $6.35 b$ & $64.66 a b$ & $8.33 a$ & $53.60 \mathrm{~b}$ & 1.88 & 0.66 & - & $135.76 b$ \\
\hline SMR1 & Herbaspirillum seropedicae & $6.00 \mathrm{e}$ & $41.00 c$ & $5.81 b$ & $57.66 b$ & $8.33 a$ & $54.10 \mathrm{~b}$ & 0.93 & 1.60 & - & $90.08 b$ \\
\hline Control & & $9.00 \mathrm{~cd}$ & $53.00 \mathrm{~b}$ & $6.81 b$ & $79.33 a$ & $8.00 a b$ & $52.10 c$ & - & - & - & - \\
\hline
\end{tabular}

IAA-Indole-3-acetic acid.
PSI-Phosphorus solubilization Index $* \mathrm{P}<0.05$. 
Table 3. Plant biomass and microbiota of wheat and corn plants in different fertilization and/or inoculation conditions.

\begin{tabular}{|c|c|c|c|c|c|c|c|c|c|c|c|c|}
\hline \multirow[b]{2}{*}{ Treatments } & \multicolumn{6}{|c|}{ Wheat } & \multicolumn{6}{|c|}{ Corn } \\
\hline & $\begin{array}{l}\text { Height } \\
\text { (cm) }\end{array}$ & $\begin{array}{c}\text { Fresh } \\
\text { Shoot }(\mathrm{g})\end{array}$ & $\begin{array}{l}\text { Dry Shoot } \\
\text { (g) }\end{array}$ & $\begin{array}{c}\text { Total } \mathrm{N} \\
\text { ( g.Kg-1) }\end{array}$ & $\begin{array}{l}\text { Epiphytic } \\
\text { UFC. } 10^{6}\end{array}$ & $\begin{array}{c}\text { Endophytic } \\
\text { UFC. } 10^{6}\end{array}$ & $\begin{array}{l}\text { Height } \\
(\mathrm{cm})\end{array}$ & $\begin{array}{c}\text { Fresh } \\
\text { Shoot }(\mathrm{g})\end{array}$ & $\begin{array}{l}\text { Dry Shoot } \\
\text { (g) }\end{array}$ & $\begin{array}{c}\text { Total } \mathrm{N} \\
\text { ( g.Kg-1) }\end{array}$ & $\begin{array}{l}\text { Epyphitic } \\
\text { UFC. } 10^{6}\end{array}$ & $\begin{array}{c}\text { Endophytic } \\
\text { UFC. } 10^{6}\end{array}$ \\
\hline \multicolumn{13}{|l|}{ Group 1} \\
\hline Control & $25.63 b$ & $0.29 a$ & $0.09 a$ & $23.60 d$ & 0 & 0 & $26.33 c$ & $1.26 c$ & $0.20 \mathrm{~b}$ & $39.00 c$ & 31 & 33 \\
\hline A. brasiliense & $27.53 b$ & $0.40 a$ & $0.11 \mathrm{a}$ & $39.90 \mathrm{bc}$ & 7 & 1.65 & $24.33 c$ & $1.27 c$ & $0.22 b$ & $56.00 \mathrm{bc}$ & 1 & 0.08 \\
\hline A. brasiliense + NPK & $23.40 \mathrm{~b}$ & $0.25 a$ & $0.08 a$ & $31.20 \mathrm{~cd}$ & 43.3 & 33.3 & $58.33 a$ & $12.88 \mathrm{a}$ & $1.48 a$ & $83.00 \mathrm{~b}$ & 25 & 5 \\
\hline A. brasiliense $+\left(\mathrm{NH}_{4}\right)_{2} \mathrm{SO}_{4}$ & $24.73 b$ & $0.35 a$ & $0.09 a$ & $47.50 \mathrm{~b}$ & 8.33 & 13.33 & $27.66 c$ & $1.74 \mathrm{c}$ & $0.23 b$ & $156.30 a$ & 21 & 20 \\
\hline A. brasiliense +NPK+($\left(\mathrm{NH}_{4}\right)_{2} \mathrm{SO}_{4}$ & $36.10 a$ & $1.18 a$ & $0.32 a$ & $60.00 a$ & 38.3 & 23.33 & $48.00 \mathrm{~b}$ & $7.47 \mathrm{~b}$ & $1.31 a$ & $140.00 \mathrm{a}$ & 1 & 20 \\
\hline \multicolumn{13}{|l|}{ Group 2} \\
\hline Control & $25.63 a$ & $0.29 \mathrm{~b}$ & $0.09 a$ & $23.60 c$ & 0 & 0 & $26.33 b$ & $1.26 \mathrm{~b}$ & $0.20 \mathrm{~b}$ & $39.00 d$ & 31 & 33 \\
\hline T 1-14 & $24.06 a$ & $0.40 a b$ & $0.11 \mathrm{a}$ & $37.40 \mathrm{~b}$ & 23.3 & 15 & $24.33 b$ & $1.28 \mathrm{~b}$ & $0.22 b$ & $57.00 \mathrm{~cd}$ & 26 & 45 \\
\hline T 1-14 +NPK & $26.73 a$ & $0.32 a b$ & $0.08 a$ & $41.90 \mathrm{~b}$ & 0.7 & 15 & $48.00 a$ & $6.85 a$ & $1.00 a$ & $93.00 \mathrm{bc}$ & 8 & 0.05 \\
\hline $\mathrm{T} 1-14+\left(\mathrm{NH}_{4}\right)_{2} \mathrm{SO} 4$ & $34.40 a$ & $0.78 a$ & $0.20 a$ & $35.90 \mathrm{~b}$ & 20 & 5 & $28.26 \mathrm{~b}$ & $1.45 \mathrm{~b}$ & $0.23 b$ & $156.30 a$ & 181 & 290 \\
\hline T 1-14 +NPK $\left(\mathrm{NH}_{4}\right)_{2} \mathrm{SO}_{4}$ & $29.80 a$ & $0.72 a b$ & $0.16 a$ & $60.10 a$ & 18.33 & 8.33 & $46.33 a$ & $5.36 a$ & $0.87 a$ & $140.00 \mathrm{a}$ & 0.5 & 41 \\
\hline \multicolumn{13}{|l|}{ Group 3} \\
\hline Control & $25.63 a$ & $0.29 a$ & 0.09a & $23.60 a$ & 0 & 0 & $26.33 c$ & $1.26 \mathrm{c}$ & $0.20 c$ & $39.00 c$ & 31 & 33 \\
\hline M 3-87 & $25.53 a$ & $0.32 a$ & $0.11 a$ & $29.20 a$ & 3.33 & 3.33 & $25.33 c$ & $1.18 \mathrm{c}$ & $0.23 c$ & $59.30 c$ & 51 & 71 \\
\hline M 3-87+NPK & $27.76 a$ & $0.37 a$ & $0.10 a$ & $40.90 a$ & 16.6 & 21.6 & $52.00 a$ & $8.80 a$ & $1.43 a$ & $102.60 \mathrm{~b}$ & 5 & 8 \\
\hline $\mathrm{M} 3-87+(\mathrm{NH} 4)_{2} \mathrm{SO}_{4}$ & $30.10 a$ & $0.40 a$ & $0.10 a$ & $39.80 a$ & 16 & 19.5 & $29.83 c$ & $1.63 \mathrm{bc}$ & $0.23 c$ & $159.00 a$ & 61 & 4 \\
\hline $\mathrm{M} 3-87+\mathrm{NPK}+\left(\mathrm{NH}_{4}\right)_{2} \mathrm{SO}_{4}$ & $31.76 a$ & $1.19 a$ & $0.24 a$ & $61.80 a$ & 1 & 0.4 & $43.00 \mathrm{~b}$ & $3.94 b$ & $0.65 b$ & $169.60 \mathrm{a}$ & 35 & 27 \\
\hline
\end{tabular}

Mediums followed by the same letter in the collumm did not differ statistically by Tukey test, at $5 \%$ probability.

Table 4. Physicochemical characteristics of the layer $0-20 \mathrm{~cm}$ soil from different collection sites.

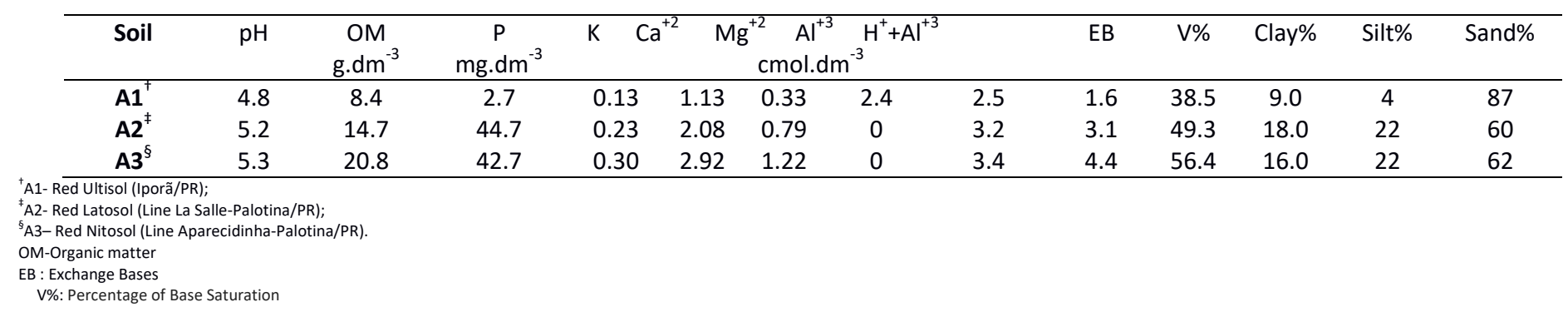


Although the TN plant levels are an indication of biological nitrogen fixation, the fixation process is energy dependent, and it is influenced by the amount and the sources of $C$ exuded by the host plant, as well as other available compounds, such as $\mathrm{NO}_{3}, \mathrm{O}_{2}$ and Mo (Bashan and De-Bashan 2010; Naher et al., 2011). A higher TN was mostly explained by fertilization (NPK and ammonium sulfate) rather than by a bacterial effect (Table 3). Re-inoculation effects were tested using strains M3-87 and T1-14, which were isolated from corn and wheat, respectively. Strain M 3-87 (Burkholderia ambifaria) was isolated from corn and showed a positive in vitro performance. However, in pots, it seemed to have a better capacity for escaping from the plant's defense system instead of increasing the root surface by IAA production (Zamioudis \& Pieterse 2012). The presence of fertilization (NPK and ammonium sulfate) could have affected the M 3-87 population in wheat plants. The bacterium could use the chemical nutrient to promote its own growth. However, Aira et al., (2010) observed an inverse proportionality in the dosage of fertilizers and bacterial activity. Shaharoona et al., (2008) found that Pseudomonas sp. inoculated in wheat with fertilizer (NPK) had reduced efficiency in proportion to the fertilizer concentration. NPK could act as a stressor, decreasing the bacterial cell's osmotic potential, and leading to death. Low natural soil fertility could have reduced the nutritional sources (carbon) for this strain, restricting its growth inside the plant. Although in vitro and in vivo conditions had different inoculation periods ( 5 and 45 days, respectively), the epiphytic and endophytic microbiota were present in the same order of magnitude $\left(10^{6}\right)$ (Table 2 and 3 ).

When T 1-14 (Pantoea ananatis) was reinoculated in pots, it also showed a positive response to fertilizer applications. The higher epiphytic and endophytic bacterial populations that were observed in vivo compared to in vitro could potentially be due to the effect of the inoculation period, as the bacteria had 45 days to achieve an association with its host plants.

\section{Materials and Methods}

\section{Sampling and sample preparation}

Corn (cv IAPAR 114) and wheat (cv CD 120) bait plants were sown in three native forest areas in the West Region of Paraná,

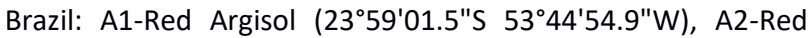
Latosol $\left(24^{\circ} 15^{\prime} 23.8^{\prime \prime} \mathrm{S} 53^{\circ} 47^{\prime} 02.8^{\prime \prime} \mathrm{W}\right)$ and A3-Red Nitossol $\left(24^{\circ} 12^{\prime} 32.7^{\prime \prime S} 53^{\circ} 45^{\prime} 27.0^{\prime \prime} \mathrm{W}\right)$, which were classified according to Bhering and Santos (2008). The areas differ in terms of their fertility and granulometry (Table 4).

Bait plants were harvested 60 days after germination, and $1 \mathrm{~g}$ of roots derived from several plants in each bait site were weighed in triplicate. The roots were washed with tap water and then sterilized in a laminar flow chamber by immersion in $70 \%$ ethanol for $30 \mathrm{~s}$, then in sodium hypochlorite (commercial product) $0.2 \%$ for $60 \mathrm{~s}$, followed by triple washing in distilled water. The roots were soaked using a mortar and pestle with 9 $\mathrm{mL}$ of saline solution $(0.9 \% \mathrm{NaCl})$.

Subsequently, serial dilutions were performed $\left(10^{1}\right.$ to $\left.10^{5}\right)$. A $0.1 \mathrm{~mL}$ sample from a $10^{5}$ dilution extract was plated in a solid medium of DYGS (Rodrigues Neto et al., 1986), NFb, JNFb, LG, LGD, LGI, or LGI-P (Döbereiner 1995). Petri dishes were placed in a $30^{\circ} \mathrm{C}$ growth chamber, except for those with LGI medium $\left(35^{\circ} \mathrm{C} \pm 2^{\circ} \mathrm{C}\right)$, for up to 7 days. The chiming of the bacteria was carried out every 7 days to obtain pure cultures. Pure cultures were stored in penicillin flasks containing a culture slant solid medium, and flasks were kept in an acclimatized dark room.

\section{Phosphate solubilization}

Bacterial phosphate solubilization was detected in vitro as the ability to solubilize phosphate by inoculation with NBRIP medium containing insoluble phosphate (Nautiyal et al., 2000). Briefly, a bacterial colony was collected with a toothpick, and each $1 / 4$ plate of NBRIP medium plate was inoculated. The presence of a halo around the colonies was considered to indicate phosphate solubilization. The plate was observed on different days for two weeks in a culture incubated at $28^{\circ} \mathrm{C}$. These colonies were stored at $-80^{\circ} \mathrm{C}$ in DYGS medium supplemented with $20 \%$ glycerol. From these measurements in triplicate, the solubilization index (SI) was obtained using the formula: $\mathrm{SI}=$ Diameter of Halo $(\mathrm{mm}) /$ Diameter of colony $(\mathrm{mm})$ (Berraquero et al., 1976). The isolates were classified as low (IS $<2$ ), medium (IS> 2) or high (IS $\geq 4$ ) potential for phosphate solubilization.

\section{In vitro IAA production}

In vitro indole acetic acid synthesis was measured by colorimetric quantitative methodology (Asghar et al., 2002). Bacterial cultures were grown in DYGS medium and incubated at $28^{\circ} \mathrm{C}$ for $24 \mathrm{~h}$. The cultures were centrifuged at $10000 \mathrm{~g}$ for $10 \mathrm{~min}$ and the supernatant was quantified spectrophotometrically at $535 \mathrm{~nm}$ with Salkowski's reagent. The IAA level was estimated according to a standard curve $(0.2$ a $45 \mu \mathrm{g} \mathrm{mL}^{-1}$ ) (Sarwar and Kremer 1995; Kuss et al., 2007). Total protein was performed following Lowry et al., (1951). All experiments were conducted in triplicate. The data were submitted to Analysis of Variance (ANOVA), and the means were grouped by the Scott-Knott test at $5 \%$ probability, with the help of the multimedia application GENES (Cruz 2006).

\section{DNA extraction and PCR amplification}

Bacterial genomic DNA was extracted following the protocol proposed by Cheng and Jiang (2006), where the bacterial strains were grown in liquid DYGS. After it was extracted, the purified DNA was stored in a freezer at $-20^{\circ} \mathrm{C}$. PCR reaction was performed using $3 \mu \mathrm{L}$ of $10 \mathrm{x}$ Taq Buffer, $2.25 \mu \mathrm{L}$ of $25 \mathrm{mM}$ $\mathrm{MgCl}_{2}, 1 \mu \mathrm{L}$ of $10 \mathrm{mM}$ of each deoxyribonucleotide, $1 \mu \mathrm{L}$ of each oligonucleotide primer $\mathrm{Y} 1 \mathrm{~F}$ (5'TGGCTCAGAACGAACGCTGGCGGC3') for the 16S rDNA gene and the Y3R primer (3'TACCTGTTACGACTTCACCCCAGTC5'), generating an amplification product comprising almost the entire gene of approximately $1.5 \mathrm{~Kb}, 2 \mu \mathrm{L}$ of Taq DNA polymerase, $2 \mu \mathrm{L}$ of DNA ( 50 to $100 \mathrm{ng}$ ) to a final volume of 30 $\mu \mathrm{L}$. Samples were amplified in a thermocycler according to the following program: $93^{\circ} \mathrm{C}$ for $2 \mathrm{~min} ; 35$ cycles of $93^{\circ} \mathrm{C}$ for $45 \mathrm{~s}$, $62^{\circ} \mathrm{C}$ for $30 \mathrm{~s}$, and $72^{\circ} \mathrm{C}$ for $2 \mathrm{~min}$; and a final extension for 5 $\min$ at $72^{\circ} \mathrm{C}$. Electrophoresis was carried at $70 \mathrm{~V}$ for approximately $1 \mathrm{~h}$ in an automated image capturer (Loccus Biotechnology L.PIX). 


\section{Partial sequencing of the 16 S rRNA gene}

To sequence the Y1-Y3 PCR products, the fragments were purified with exo /SAP enzymes (protocol according to the manufacturer) and sequenced using dye terminator chemistry in a sequencer $\mathrm{XL} A \mathrm{BI} 3500$ Genetic Analyzer (Applied Biosystems). Nucleotide sequence identities were determined by the Blast and Seqmatch programs and were used to taxonomically classify the sequences according to the bacterial taxonomy proposed by Bergey's Trust or were classified using the NCBI RDP site (Ribosomal Database Project http://rdp.cme.msu.edu).

\section{In vitro plant growth promoting assay}

To determine the capacity of plant interaction among isolates, 4 bacterial strains ( $\mathrm{T} 1-1, \mathrm{~T} 1-14, \mathrm{M} 2-77$, and $\mathrm{M}$ 3-87) varying in terms of IAA production, phosphate solubilization and type of bait plants were tested in vitro. The bacteria Azospirillum brasilense Ab-V5 and Herbaspirillum seropedicae SMR1 were used as positive controls, and the negative control was not inoculated. Fifty seeds of wheat genotype CV CD 120 (responsive to association) (Neiverth et al., 2014) were aseptically prepared using acidified hypochlorite solution and were pregerminated in agar-water medium for $24 \mathrm{~h}$. The inoculum was prepared from a colony of each strain and was transferred to a preinoculum containing $5 \mathrm{~mL}$ medium DYGS liquid in a $50 \mathrm{~mL}$ conic tube and maintained at $28^{\circ} \mathrm{C}$ in a shaker (120 rpm/overnight). One $\mathrm{mL}$ of the preinoculum was transferred to a $20 \mathrm{~mL}$ DYGS liquid medium until the log phase of growth was reached. The cell mass was measured by turbidimetry at $660 \mathrm{~nm}$. For inoculation, the concentration used was $10^{6}$ cells per pregerminated seed. The seeds were dried at room temperature for $2 \mathrm{~h}$ and then transferred to test tubes containing $20 \mathrm{~mL}$ of MS medium (Murashige and Skoog 1962) containing polypropylene balls, which formed a $5-\mathrm{cm}$ support layer for seeds without the addition of nitrogen at $\mathrm{pH}$ 5.8. Each tube received a pregerminated seed and 10 replications were done per treatment in a complete randomized design. Tubes were disposed in a growth chamber under a photoperiod of $16 \mathrm{~h}$ light / $8 \mathrm{~h}$ dark with a temperature of $25 \pm 2^{\circ} \mathrm{C}$ for 5 days. After 5 days of culture, three seedlings from each treatment were removed from the tubes and the shoot and roots were separated. Plant height, root length, fresh weight $(\mathrm{mg})$ of shoot and root were measured. These samples were dried with air circulation at $65^{\circ} \mathrm{C}$ for $48 \mathrm{~h}$ to obtain the dry weight of shoot and root. The shoot dry matter was used to analyze the total nitrogen content (TN) (Kjeldahl) according to the method described by Bremner and Mulvaney (1982).

\section{Counting of epiphytic and endophytic bacterial cells in roots}

For assessment of the epiphytic bacterial cell count, $0.1 \mathrm{~g}$ from in vitro cultivated wheat roots was immersed in tubes containing $1 \mathrm{~mL}$ saline (0.9\%) and taken to the sonicator for 1 $\min$. Then, $100 \mu \mathrm{L}$ sample aliquots were taken and inoculated into micro tubes with $900 \mu \mathrm{L}$ of saline $(0.9 \%)$. This procedure was performed until the $10^{8}$ dilution. For endophytic bacterial cell counting, the same roots used for epiphytic counting were immersed in a solution of Chloramine - T $1 \%$ for $30 \mathrm{~s}$, then rinsed with distilled water and autoclaved. Next, the roots were ground in $1 \mathrm{~mL}$ saline $(0.9 \%)$ and placed in the sonicator for $1 \mathrm{~min}$, and the 8 dilutions were performed as described above. The dilutions were allocated on a single Petri dish containing DYGS solid medium, where each of the 3 microdrops $(5 \mu \mathrm{L})$ of dilution constituted the replicates (Romeiro 2001). The plates were placed in a growth chamber at $28^{\circ} \mathrm{C}$ and the bacterial cells were counted after $16 \mathrm{~h}$.

\section{In vivo plant growth promoting assay}

In vivo experiments were conducted to evaluate the plant growth promotion in wheat and corn. Treatments with inoculation and/or fertilization in a low fertility (LF) (Red Argisol) soil were conducted: $\mathrm{pH}=3.6, \mathrm{OM}=1.34 \mathrm{~g} \mathrm{dm}^{-3}, \mathrm{P}=$ $2.8 \mathrm{~g} \mathrm{dm}^{-3}, \mathrm{Ca}^{+2}=0.87 \mathrm{cmol} . \mathrm{dm}^{-3}, \mathrm{Mg}^{+2}=0.14 \mathrm{cmol}^{+\mathrm{dm}^{-3}}, \mathrm{Al}^{+3}=$ $1 \mathrm{cmol} . \mathrm{dm}^{-3}, \mathrm{~K}^{+1}=0.02 \mathrm{cmol}^{-\mathrm{dm}^{-3}}, \mathrm{Fe}=26 \mathrm{mg} \mathrm{dm}^{-3}, \mathrm{CEC}=1.2 \mathrm{~V}$ $=25 \%$, clay $=6.0 \%$, sand $=76 \%$. Five seeds of wheat (cv. $\mathrm{CD} 120$ ) and corn (Pioneer 30F53) were inoculated with strains T 1-14, M 3-87 and Azospirillum brasilense Ab-V5 composing 3 groups with 4 different treatments: 1 - Strain $\left(10^{6}\right.$ cells.seed $\left.^{-1}\right)$, 2- Strain +NPK (400 kg ha $\left.{ }^{-1}\right)(4-20-20)$, 3-Strain+Ammonium sulfate $\left(50 \mathrm{~kg} \mathrm{ha}^{-1}\right)$ in coverage and 4- Strain + NPK + Ammonium sulfate in coverage in pots containing $4.5 \mathrm{~kg}$ of previously sifted soil. Strains and fertilizers were not added to the control treatments.

Thinning was done 15 days after sowing, leaving only three plants per pot. The experimental design was a 3 (strains) $\times 4$ (fertilization/inoculation conditions) factorial completely randomized, with each group conducted in triplicate. After 30 days of sowing, ammonium sulfate was used in coverage. The final evaluation of growth promotion was held 45 days after sowing and was evaluated based on plant height, shoot fresh weight, dry matter of shoot and total nitrogen in the leaf tissue, as previously described. Bacterial cell counting was performed by collecting intact roots from pots, which were cut and washed in running water to remove excess soil. For each sample, $0.5 \mathrm{~g}$ was taken to a laminar flow hood, where previously proposed protocol was followed.

\section{Statistical analysis}

Data were submitted to Analysis of Variance (ANOVA) by F-test at $5 \%$ probability and the means were compared by a Tukey test at $5 \%$ probability using the GENES statistical program (Cruz 2006).

\section{Conclusion}

An understanding of bacterial endophytic strain diversity is important in ecological and biotechnical applications, as the soil's bacterial community continually interacts with plants that are competing for nutrients and water, thus forming a complex ecosystem. Not all of the isolates demonstrated IAA and PSI capacities, which are markers of promising biofertilizer strains. Isolates showed distinct performances under in vitro and in vivo conditions. In vivo experiments displayed a 
prominent response by the endophytic population due to the presence of fertilizer, confirming that microbiota are highly influenced by soil fertility. Additionally, it was observed that plant genotype had a strong influence on limiting or promoting the endophytic bacterial population.

\section{Acknowledgements}

The authors would like to thank technician Valter Baura for his help with sequencing analysis. They would also like to acknowledge CAPES, the Araucaria Foundation for the Support of Scientific and Technological Development of Paraná, affiliates with State Secretary of Science, Technology and Higher Education - SETI, CAPES / PNPD, and the INCT - FBN for financial support and CNPq for granting a productivity scholarship to researcher Dr. Vandeir Francisco Guimarães.

\section{References}

Ahmad N, Johri S, Abdin MZ, Qazi GN (2009) Molecular characterization of bacterial population in the forest soil of Kashmir. W J Microbiol Biotech. 25:107-113.

Aira M, Lazcano C, Gómez-Brandón M, Domínguez J (2010) Aging effects of casts of Aporrectodea caliginosa on soil microbial community structure and activity. Applied Soil Ecol. 46:143-146.

Arruda L, Beneduzi A, Martins A, Lisboa B, Lopes C, Bertolo F, Passaglia LMP, Vargas LK. (2013) Screening of rhizobacteria isolated from maize (Zea mays L.) in Rio Grande do Sul state (south Brazil) and analysis of their potential to improve plant growth. Applied Soil Ecol. 63:15-22.

Arzanesh MH, Alikhani HA, Khavazi K, Rahimian HA, Miransari M (2011) Wheat (Triticum aestivum L.) growth enhancement by Azospirillum sp. under drought stress. W J Microbiol Biotech. 27:197-205.

Asghar H, Zahir Z, Arshad M, Khaliq A (2002) Relationship between in vitro production of auxins by rhizobacteria and their growth-promoting activities in Brassica juncea L. Biol Fertil Soils. 35:231-237.

Bashan Y, De-Bashan L (2010) How the plant growthpromoting bacterium Azospirillum promotes plant growth - a critical assessment. Adv Agron. 108:77-136.

Baudoin E, Benizri E, Guckert A (2003) Impact of artificial root exudates on the bacterial community structure in bulk soil and maize rhizosphere. Soil Biol Bioch. 35:1183-1192.

Beneduzi A, Moreira F, Costa PB, Vargas LK, Lisboa BB, Favreto R, Baldani JI, Passaglia LMP (2013) Diversity and plant growth promoting evaluation abilities of bacteria isolated from sugarcane cultivated in the south of Brazil. Applied Soil Ecol. 63:94-104.

Berg G (2009) Plant microbe interactions promoting plant growth and health: perspectives for controlled use of microorganisms in agriculture. Applied Microbiol Biotech. 84:11-18.

Berraquero FR, Baya AM, Cormenzana AR (1976) Establishment of indices for the study of phosphate solubilization by soil bacteria. Ars Pharmacéutica. 17:399406.
Bhering SB, Santos HG, Bognola IA, Curcio GB, Carvalho Júnior WC, Chagas CS, Manzatto CV, Áglio MLD, Silva JS (2009) Mapa de solos do estado do Paraná, legenda atualizada. Paper presented at the XXXII congresso brasileiro de ciência do solo, Fortaleza, 2-7 august 2009.

Bouffaud M-L, Kyselková M, Gouesnard B, Grundmann G, Muller D, Moënne-Loccoz $Y$ (2012) Is diversification history of maize influencing selection of soil bacteria by roots? Mol Ecol. 21:195-206.

Bremner, J.M. and Mulvaney, C.S. (1982) Nitrogen-Total. In: Methods of soil analysis. Part 2. Chemical and microbiological properties, Page, A.L., Miller, R.H. and Keeney, D.R. Eds., Agricultural Sciences. 2:595-624.

Castanheira N, Dourado AC, Kruz S, Alves PIL, DelgadoRodríguez Al, Pais I, Semedo J, Scotti-Campos P, Sánchez C, Borges N (2016) Plant growth-promoting Burkholderia species isolated from annual ryegrass in portuguese soils. J Applied Microbiol. 120:724-739.

Chaturvedi H, Singh V (2016) Potential of bacterial endophytes as plant growth promoting factors. J Plant Pathol Microbiol. 7:9.

Cheng HR, Jiang N (2006) Extremely rapid extraction of DNA from bacteria and yeasts. Biotech Lett. 28:55-59.

Compant S, Nowak J, Coenye T, Clément C, Ait Barka E (2008) Diversity and occurrence of Burkholderia spp. in the natural environment. FEMS Microbiol Rev. 32:607-626.

Compant S, Reiter B, Sessitsch A, Nowak J, Clément C, Ait Barka E (2005) Endophytic colonization of Vitis vinifera L. by plant growth-promoting bacterium Burkholderia sp. strain PsJN. Applied Environ Microbiol. 71:1685-93.

Cruz CD (2006) Programa Genes - estatística experimental e matrizes. UFV.

de-Bashan LE, Hernandez J-P, Morey T, Bashan Y (2004) Microalgae growth-promoting bacteria as "helpers" for microalgae: a novel approach for removing ammonium and phosphorus from municipal wastewater. Water Res. 38:466474.

Dey R, Pal KK, Tilak KVBR (2012) Influence of soil and plant types on diversity of rhizobacteria. Proc Nat Acad Sci. 82:341-352.

Döbereiner, J., Baldani, V. L. D., \& Baldani, J. I. (1995). Como isolar e identificar bactérias diazotróficas de plantas nãoleguminosas. Embrapa SPI.

Donn S, Kirkegaard JA, Perera G, Richardson AE, Watt M (2015) Evolution of bacterial communities in the wheat crop rhizosphere. Environ Microbiol. 17:610-21.

Doornbos RF, Van Loon LC, Bakker PAHM (2012) Impact of root exudates and plant defense signaling on bacterial communities in the rhizosphere. A review. Agron Sustainable Develop. 32:227-243.

Drogue B, Doré H, Borland S, Wisniewski-Dyé F, PrigentCombaret C (2012) Which specificity in cooperation between phytostimulating rhizobacteria and plants? Res Microbiol. 163:500-510.

Egamberdiyeva D (2007) The effect of plant growth promoting bacteria on growth and nutrient uptake of maize in two different soils. Applied Soil Ecol. 36:184-189. 
Farrar K, Bryant D, Cope-Selby N (2014) Understanding and engineering beneficial plant-microbe interactions: plant growth promotion in energy crops. Plant Biotech J.12:1193206.

Fürnkranz M, Müller H, Berg G (2009) Characterization of plant growth promoting bacteria from crops in Bolivia. J Plant Diseases Protect. 116:149-155.

Gaiero JR, McCall CA, Thompson KA, Day NJ, Best AS, Dunfield KE (2013) Inside the root microbiome: bacterial root endophytes and plant growth promotion. Am J Bot. 100:1738-1750.

García de Salamone IE, Funes JM, Di Salvo LP, Escobar-Ortega JS, D'Auria F, Ferrando L, Fernandez-Scavino A (2012) Inoculation of paddy rice with Azospirillum brasilense and Pseudomonas fluorescens: impact of plant genotypes on rhizosphere microbial communities and field crop production. Applied Soil Ecol. 61:196-204.

Hardoim PR, van Overbeek LS, Berg G, Pirttilä AM, Compant S, Campisano A, Döring M, Sessitsch A (2015) The hidden world within plants: ecological and evolutionary considerations for defining functioning of microbial endophytes. Microbiol Mol Biol Rev 79:293-320.

Hardoim PR, van Overbeek LS, Elsas JD van (2016) Properties of bacterial endophytes and their proposed role in plant growth. Trends Microbiol. 16:463-471.

Hawkesford MJ (2014) Reducing the reliance on nitrogen fertilizer for wheat production. J Cereal Sci. 59:276-283.

Ilyas N, Bano A (2010) Azospirillum strains isolated from roots and rhizosphere soil of wheat (Triticum aestivum L.) grown under different soil moisture conditions. Biol Fertility Soils 46:393-406.

Khalid A, Arshad M, Zahir ZA (2004) Screening plant growthpromoting rhizobacteria for improving growth and yield of wheat. J Applied Microbiol. 96:473-480.

Kirzinger MWB, Stavrinides J (2016) Host specificity determinants as a genetic continuum. Trends Microbiol. 20:88-93.

Kuss AV, Kuss VV, Lovato T, Flôres ML (2007) Fixação de nitrogênio e produção de ácido indolacético in vitro por bactérias diazotróficas endofíticas. Pesq Agropec Bras. 42:1459-1465.

Lagos ML, Maruyama F, Nannipieri P, Mora ML, Ogram A., Jorquera MA (2015) Current overview on the study of bacteria in the rhizosphere by modern molecular techniques: a mini-review. J Soil Sci Plant Nutrition 15:504-523.

Lowry OH, Rosebrough NJ, Farr AL, Randall RJ (1951) Protein measurement with the folin phenol reagent. J Biol Chem. 193:265-275.

Majeed A, Kaleem Abbasi M, Hameed S, Imran A, Rahim N (2015) Isolation and characterization of plant growthpromoting rhizobacteria from wheat rhizosphere and their effect on plant growth promotion. Front Microbiol. 6:1-10.

Marschner P, Crowley D, Rengel Z (2011) Rhizosphere interactions between microorganisms and plants govern iron and phosphorus acquisition along the root axis - model and research methods. Soil Biol. 43:883-894.

Mendes R, Pizzirani-Kleiner AA, Araujo WL, Raaijmakers JM (2007) Diversity of cultivated endophytic bacteria from sugarcane: genetic and biochemical characterization of
Burkholderia cepacia complex isolates. Applied Environ Microbiol. 73:7259-7267.

Moreira FS, Costa PB, Souza R De, Beneduzi A, Lisboa BB, Vargas LK, Passaglia LMP (2016) Functional abilities of cultivable plant growth promoting bacteria associated with wheat (Triticum aestivum L.) crops. Genet Mol Biol. 39:111121.

Murashige T, Skoog F (1962) A revised medium for rapid growth and bio assays with tobacco tissue cultures. Physiol Plantarum. 15:473-497.

Murray FR, Latch GCM, Scott DB (1992) Surrogate transformation of perennial ryegrass, Lolium perenne, using genetically modified acremonium endophyte. Mol Gen Genet. 233:1-9.

Naher UA, Radziah O, Halimi MS, Shamsuddin ZH, Razi IM (2011) Effect of root exuded specific sugars on biological nitrogen fixation and growth promotion in rice (Oryza sativa). Aust J Crop Sci. 5:1210-1217.

Nautiyal CS, Bhadauria S, Kumar P, Lal H, Mondal R, Verma D (2000) Stress induced phosphate solubilization in bacteria isolated from alkaline soils. FEMS Microbiol Lett. 182:291296.

Neiverth A, Delai S, Garcia DM, Saatkamp K, de Souza EM, Pedrosa FDO, Guimarães VF, dos Santos MF, Vendruscolo ECG, da Costa ACT (2014) Performance of different wheat genotypes inoculated with the plant growth promoting bacterium Herbaspirillum seropedicae. Eur J Soil Biol. 64:1-5.

Neumann G (2007) Root exudates and nutrient cycling. In: Marschner, P., Rengel Z (Eds) Nutrient Cycling in Terrestrial Ecosystems. Springer. 123-158.

Prathap M, Ranjitha Kumari B (2015) Plant pathology \& microbiology a critical review on plant growth promoting rhizobacteria. J Plant Pathol Microbiol. 6:4-7.

Rashid S, Charles TC, Glick BR (2012) Isolation and characterization of new plant growth-promoting bacterial endophytes. Applied Soil Ecol. 61:217-224.

Reis VM (2007) Uso de bactérias fixadoras de nitrogênio como inoculante para aplicação em gramíneas. Embrapa Agrobiologia-Documentos (INFOTECA-E).

Rodrigues Neto J, Malavolta Jr V, Victor O (1986) Meio simples para isolamento e cultivo de Xanthomonas campestris pv. citri tipo B. Summa Phytopath. 12:16.

Rodríguez H, Fraga R (1999) Phosphate solubilizing bacteria and their role in plant growth promotion. Biotechn Adv. 17:319-339.

Roesch LFW, Passaglia LMP, Bento FM, Triplett EW, Camargo FAO (2007) Diversidade de bactérias diazotróficas endofíticas associadas a plantas de milho. Rev Bras Ciên Solo 31:13671380.

Rojas-Tapias D, Moreno-Galván A, Pardo-Díaz S, Obando $M$, Rivera D, Bonilla R (2012) Effect of inoculation with plant growth-promoting bacteria (PGPB) on amelioration of saline stress in maize (Zea mays). Applied Soil Ecol. 61:264-272.

Rolli E, Marasco R, Vigani G, Ettoumi B, Mapelli F, Deangelis ML, Gandolfi C, Casati E, Previtali F, Gerbino R, Cei FP, Borin S, Sorlini C, Zocchi G, Daffonchio D (2015) Improved plant resistance to drought is promoted by the root-associated microbiome as a water stress-dependent trait. Environ Microbiol. 17:316-31. 
Romeiro RS (2001) Métodos em bacteriologia de plantas. Viçosa-MG: UFV.

Romero FM, Marina M, Pieckenstain FL (2014) The communities of tomato (Solanum lycopersicum L.) leaf endophytic bacteria, analyzed by 16S-ribosomal RNA gene pyrosequencing. FEMS Microbiol Lett. 351:187-194.

Sala VMR, Cardoso EJBN, Freitas JG, Silveira APD (2008) Novas bactérias diazotróficas endofíticas na cultura do trigo em interação com a adubação nitrogenada, no campo. Rer Bras Ciên Solo. 32:1099-1106.

Sarwar M, Kremer RJ (1995) Determination of bacterially derived auxins using a microplate method. Lett Applied Microbiol. 20:282-285.
Shaharoona B, Naveed M, Arshad M, Zahir ZA (2008) Fertilizerdependent efficiency of Pseudomonads for improving growth, yield, and nutrient use efficiency of wheat (Triticum aestivum L.). Applied Microbiol Biotech. 79:147-155.

Singh JS, Abhilash PC, Singh HB, Singh RP, Singh DP (2011) Genetically engineered bacteria: an emerging tool for environmental remediation and future research perspectives. Gene. 480:1-9.

Weyens N, van der Lelie D, Taghavi S, Vangronsveld J (2009) Phytoremediation: plant-endophyte partnerships take the challenge. Curr Op Biotech. 20:248-254.

Zamioudis C, Pieterse CMJ (2012) Modulation of host immunity by beneficial microbes. Mol Plant-Microbe Inter. 25:139150. 